\title{
Muutustest eesti keele grammatiliste käänete kasutamisel
}

\author{
PILLE ESLON \\ Tallinna Ülikool
}

Ülevaade. Artiklis võrreldakse grammatiliste käänete sagedust ning kasutuseelistusi eesti kirjakeeles ja õppijakeeles. Eesmärk on pakkuda teavet keelemuutuslike protsesside kohta, mida võivad esile kutsuda erinevad asjaolud: analoogiale tuginev keelesisene areng universaalses grammatisatsiooniprotsessis või kontaktsituatsioonis tekkinud analoogia mudelkeele konstruktsioonidega.

Võtmesõnad: eesti keele grammatilised käänded; analoogiale tuginevad keelemuutused; grammatisatsioon

\section{Metodoloogilisi ääremärkusi}

Kõnekeeles ja kirjasõnas tuleb ette ebakorrektsusi, mida emakeelekõneleja ei pane tähelegi, samas jälgivad teise keele või võõrkeeleõppijad ja õpetajad ning keeletoimetajad normidest ja reeglitest kinnipidamist erilise usinusega. Näitena võiks tuua muutused sõnade valentsimustrites ja objektnoomeni käändevalikus.

Muutused sõnade valentsimustrites võivad olla tingitud morfoloogilistest teguritest ja nihetest verbide, nimisõnade, adjektiivide argumendistruktuuris, mis omakorda on seotud sõnade grammatiliste funktsioonide ja semantiliste rollidega. Lause sõnajärje ja sõnade semantiliste rollide muutudes hakkavad varieeruma ka valentsimustrid (vt Haspelmath, Müller-Bardey 2001). Tekib olukord, kui emakeelekõnelejal on raske otsustada, kas öelda ühed naudivad mängimisest 
(millest?) või mängimist (mida?), sest mõlemad variandid tunduvad loomulikud ${ }^{1}$. Samuti on raske otsustada, millist käänet kasutada verbiga sarnanema: --- ütles, et eksitus tekkis, sest tšekk sarnanes kütusearvele (Postimees 25.10.2007) või --- ütles, et eksitus tekkis, sest tšekk sarnanes kütusearvega jne. Veidi teistmoodi on hinnatav kasutus *inimesed siia (kuhu?) või siin (kus?) puhkamas ei käi, kus esimene valentsimuster on selgelt venemõjuline (vene verb käima nõuab illatiivi, mitte inessiivi nagu eesti keelele omane) ja seega keelekontaktist tulenev muutus.

Ka grammatiliste käänete kasutamisel teeb nii eesti keele õpetajatele kui ka keeleteadlastele üha enam peavalu, et partitiiv allutab genitiivse ja nominatiivse objektnoomeni alasid, kusjuures põhjused võivad olla erinevad: Vitali kohta rakendati lähenemise keeldu (Kanal 2: Reporter) $\sim$ Vitali suhtes rakendati lähenemiskeeld; Noored lópetavad siin gümnaasiumit (Kanal 2: Reporter) Noored lópetavad siin gümnaasiumi; Ta mõistis vanema munga käitumist hukka (Vikerraadio: hommikupalvus) Ta mõistis vanema munga käitumise hukka; Hispaania alistas Venemaa koondist 4:1 (ETV: Sport) Hispaania alistas Venemaa koondise $4: 1$ jne.

Keelekorraldajate, toimetajate, õppijate ja õpetajate jaoks on igasugused muutused, mis ei vasta normile, negatiivne signaal (vt Holroyd, Coles 2002). Keeleuurija seisukoht on selles suhtes sallivam ja hinnangulisi määratlusi enamasti vältiv (vt Keevallik jt 2006: 611) või ettevaatlik ning terminoloogilisi kitsendusi ja piiranguid kehtestav (vt Argus 2008: 12 jj). Lingvisti vaatepunktist on igasugusel keelekasutusel oma kindel tähendus. Ühelt poolt on see allikmaterjal, mida saab uurida, et leida sarnasusi/erinevusi näiteks normkirjakeele ja kõnekeele või standardkeele (kirjakeele) ja õppijakeele kui ühe ja sama keele erinevate kasutusvariantide vahel. Teisalt on ebareeglipärasustel ka oluline metodoloogiline tähendus. Mõte on selles, et kõrvalekalded keelenormist on omamoodi indikaator, mis annab lingvistile märku keele-

\footnotetext{
$1 \quad$ Valentsinäited pärinevad Peep Nemvaltsi ettekandest "Alaleütleva allutusretked võorale alale”, mis peeti Tallinna Ülikoolis Muutuva keele päeval 16. novembril 2007.
} 
süsteemis kulgevatest arengutest (nt semantiliste, pragmaatiliste või morfosüntaktiliste eelistuste kujunemine vormimoodustuses ja -kasutuses), raskuspunktidest keele kirjeldamisel (nt kaassõnade ja adverbide eristamine), keelekontaktidest tulenevatest mõjudest ja samalaadsetest iseseisvalt kulgevatest arengutest tüpoloogiliselt erinevates keeltes (nt vormivariatiivsuse tekkimine, muutused verbi rektsioonistruktuurides, lause sõnajärje muutumine), reeglite ebatäpsusest jm. Neid signaale ei saa pidada ainult positiivseteks või ainult negatiivseteks, sest keel on olemuselt dialektiline ning ebareeglipärasused on loomingulisuse lahutamatu osa. Seetõttu ei saa ka keelelist variatiivsust vaadelda ebamugavusena, mis takistab suhtlust: tänu leksikaalsete ja grammatiliste üksuste varieerumisvõimele avaneb keelesüsteemi funktsionaalne potentsiaal, andes meie käsutusse järjest uusi vahendeid mõtete täpsemaks väljendamiseks (Remchukova 2005: 14-15). Seda protsessi on nimetatud ka keele järjepidevaks tsükliliseks uuenemiseks (Maisak 2005: 76), mille käigus teadlikult või ebateadlikult eksitakse - eksivad nii emakeelekõnelejad kui ka sama keelt teise või võõrkeelena õppijad. See on paratamatu ja loomulik nähtus. Erinevus emakeele ja teise või võõrkeele vahel seisneb siin selles, et õppijakeele mittevastavus standardkeele normidele tuleb enamasti selgelt esile, sest korduvad, mõningal juhul ka kivinenud keelevead paistavad silma ja on identifitseeritavad, samas kui emakeelekõnelejate keelenormile mittevastavat sõna- või vormikasutust võiks nimetada pigem etapiks mõtte täpsemal ning ökonoomsemal väljendamisel. Seejuures tuleb ette ka niisuguseid arenguid, mida ühe keele või keelevariandi põhjal tehtud lingvistilise analüüsiga ei pruugi leida. Siinkohal avanebki õppijakeele ees võimalus panustada nt kirjakeele uurimisse, sest teise või võõrkeele õppimine tugineb eelkõige emakeelekõneleja sünkroonsele keelekasutusele ja kajastab seetõttu õpitavale keelele omaseid arengutendentse reljeefsemalt kui standardkeel. On märgitud (vt Sõrmus 2008: 35), et uueneva keelekasutuse võtavad kergemini omaks just keeleõppijad, kuna nad on sellele kõige vastuvõtlikumad. Nende keelekasutus peegeldab "ajakirjandus- ja internetikeele mõjul üldkeeles toimuvaid muutusi" paremini kui täiskasvanud emakeelekõnelejate keel. 
Järelikult on keelemuutuste uurimisel ühe ja sama keele erinevate kasutusvariantide võrdlemine (nt murdekeel - kirjakeel - veebikeel õppijakeel) üks metodoloogilistest printsiipidest, mis annab võimaluse leida keele süsteemis muutustele avatud piirkondi ning mõtestada keele uuenemisprotsesse, prognoosida nende edasist kulgu ja tõenäosust. Selle printsiibi rakendamine pole eesti keele uurimises veel juurdunud. Tehtud on esimesed katsed võrrelda eesti kirjakeele ja õppijakeele käändesagedust ning käändevormide kasutuseelistusi korpusest tulenevalt, integreerides erinevaid kvantitatiivse analüüsi meetodeid ja eesti keele tarkvara (vt Eslon, Matsak 2009; Eslon 2009; Eslon 2008). Vajadust vastavate uuringute järele on tunnetatud (vt Kaivapalu 2008; Sõrmus 2008), kuid seni on õppijakeele objektnoomeni käändevariatiivsust uuritud kas veaanalüüsi võtmes (vt Pool 2007) või psühholingvistiliselt ja kontaktsituatsioonist tulenevalt (vt Ehala 2009)2 . Võrdluseks võib öelda, et ka inglise keele erinevate kasutusvariantide võrdlemisel on keelemuutuslikke protsesse suhteliselt vähe uuritud (vt Cobb 2003: 419). Teadlasi on rohkem huvitanud, kuidas inimene sõnu erinevates keeltes valib ja neid teiste sõnadega seostab (nt Sinclair 1991, 2004; Nesselhauf 2005; Muischnek 2006; Jantunen 2007, 2008), missugune on sõnade kasutusgrammatika (nt Tono, Aoki 1998), milliseid etappe läbib õppija teksti produtseerides, liikudes sõnalt fraasile, fraasilt lausele, lauselt terviktekstile (vt Petch-Tyson 1998: 107-118; Stubbs 1996; Orpin 2005), missugused stereotüübid on seejuures täheldatavad (nt Granger 1998; Ringbom 1998: 41-52; Cobb 2003: 393-423) jne.

Teine oluline metodoloogiline printsiip, mida tuleb silmas pidada ( $\mathrm{ja}$ mitte ainult erinevate keelevariantide võrdlemisel), seisneb uurimissuuna valikus. Korpuslingvistikas on rakendatud korpusest tulenevat uurimist

2 Uurimuse aluseks on tajutest, milles nii eesti kui ka vene emakeelega kooliõpilastel on palutud hinnata Likert-skaala alusel objektnoomeni käändevariatiivsust erinevates kontekstitüüpides. Eesmärk on välja selgitada, mil määral on vormikasutusnihked põhjustatud keelekontaktidest. Saadud andmeid on töödeldud erinevate statistiliste meetodite abil, mis on võimaldanud esile tuua ka neid tendentse objektnoomeni käändevormide kasutuses, mis eesti-vene keele kontaktsituatsioonist ei johtu. 
(ingl corpus-driven research) ja korpuspõhist keeleanalüüsi (corpus-based language analysis). Omavahel integreerituna pakuvad need kaks suunda põhimõtteliselt uusi võimalusi nii kvalitatiivseks kui ka kvantitatiivseks analüüsiks (vt Behrens 2008: XXVII; Orpin 2005: 38-39 jt). Korpusest tuleneva uurimise eelis on selles, et uurija ei lähtu etteantud seisukohtadest või kindlast keeleainesest, vaid laseb ennast korpusel juhtida. Selleks töödeldakse kindlate põhimõtete alusel koostatud korpust erineva tarkvara abil, rakendatakse kvantitatiivse analüüsi meetodeid ja statistilist andmetöötlust. Nii saadakse teavet selle kohta, mis ühele või teisele keelevariandile tegelikult iseloomulik on ning võib seetõttu üldse uurijale huvi pakkuda (Tognini Bonelli 2002)3. Näiteks tehakse kindlaks erinevate keelevariantide sõna- ja vormisagedus; saadakse statistilisi andmeid sõna, lause ja teksti pikkuse, korrektse/ebakorrektse keelekasutuse vahekorra kohta (nt tüüpiliste/ebatüüpiliste kollokatsiooniliste sõnaühendite suhe teatud tekstiliigis või erinevates keelevariantides); tuuakse välja sõnadevahelisi semantilisi ja grammatilisi seoseid jne. Seevastu korpuspõhist keeleanalüüsi on rakendatud enamasti eesmärgiga leida kinnitust mingitele kindlatele teoreetilistele seisukohtadele, konkreetsetele hüpoteesidele või selleks, et uurida suuremahulise keeleainese peal teatud keelendite või vormide funktsioone ning kasutusvõimalusi (vt nt Kennedy 2002; Gabrielatos 2007).

Kolmas metodoloogiline printsiip, mida keelemuutuste mõtestamisel ning kirjeldamisel erinevate keelevariantide võrdleva uurimisega seoses peaks silmas pidama, on loomuliku morfoloogia teooria põhimõtted (vt Wurzel 1984; Langacker 1999; Ehala 1997). Loomulikud nähtused on keelele tüpoloogiliselt omased, seega tavalised, markeerimata ning neid kasutatakse markeeritud üksustest sagedamini (Keevalik jt 2006: 613) jne. Neid saab nimetada keelesüsteemi tuumelementideks, mis on muutuste suhtes tundlikumad kui markeeritud elemendid. Järelikult protsessid, mis tuumelementidega aset leiavad, on osa universaalsest grammatisatsiooniprotsessist (vt Heine, Kuteva 2008: 59-76). See on

Vt ka sellesuunalisi diskursusanalüüsi uurimusi: Stubbs 1996; Orpin 2005; Hoey jt 2007 jt. 
loomulik nähtus, milles sotsiokultuurilised faktorid mängivad vähemolulist rolli kui keeletüpoloogilised ${ }^{4}$. Keelemuutused on sama paratamatud ja loomulikud kui kõik dialektilised arenguprotsessid - neid on vaja keele säilimiseks. Võrreldes andmeid keelesisese ja keelekontaktidest tuleneva grammatisatsiooni kohta erinevates keeltes (vt Heine, Kuteva 2008), võib nende kahe suuna vahel märgata vastastikust sõltuvust: seal, kus puuduvad eeldused keelesisesteks muutusteks, puudub ka reaalne võimalus keeltevahelistest seostest tulenevateks muutusteks (vt R. Grünthal 2003).

\section{Analüüsitud materjal ja meetodid}

Uurimisobjekt on eesti keele grammatilised ehk abstraktsed käänded, mille kasutamist võrreldakse kahe korpusainestiku alusel. Eesti kirjakeele analüüsimaterjal on saadud Eesti Keele Instituudi tekstikorpusest $^{5}$ (edaspidi EKI korpus), õppijakeele näitematerjal pärineb Tallinna Ülikooli Eesti vahekeele korpuse ${ }^{6}$ (edaspidi EVKK) tekstidest. Grammatiliste käänete kasutamist uuritakse mõlema korpuse sagedasemate nimisõnade inimene, aeg, elu ja sõna alusel ${ }^{7}$. Kuna EKI korpus ja EVKK on avatud ehk monitorkorpused, siis sisaldasid korpuste üldvalimid analüüsi tegemise hetkel 2008. aasta septembris-oktoobris nimisõnade inimene, aeg, elu ja sõna erinevaid käändevorme vastavalt 98928 (EKI korpus) ja 19433 (EVKK). Nende üldvalimite puhul on tõeste tulemuste saamiseks piisav niisugune korpusaines, mis koosneb 7000 tekstilõigust ${ }^{8}$. Tähelepanu keskmes on kaks nähtust: käändevormide sagedus mõlema korpuse tekstides ning nendes leksikaalgrammatilistes konstruktsioo-

$4 \quad$ Mõttevahetust selle kohta vt Thomason, Kaufman 1988; Aikhenvald 2002; Thomason 2008; Heine, Kuteva 2008.

$5 \quad$ Vt http://www.eki.ee/corpus/ (3.09.2008).

$6 \quad$ Vt http://evkk.tlu.ee $(28.10 .2008)$.

7 Et sagedasemate nimisõnade esiletoomise põhimõtted on kirjeldatud artiklis Eslon 2008: 33-35, siis siinkohal sellel pikemalt ei peatuta.

$8 \quad$ Valimite representatiivsuse määramise aluseks on olnud statistiline olulisustõenäosus; vastavad arvutused on teinud Erika Matsak (vt Eslon, Matsak 2009: 82-84). 
nides, mida erinevad keelekasutajad on tekste produtseerides eelistanud. Saadud andmete põhjal on võimalik välja tuua vormisagedust ja vormi kasutuseelistusi iseloomustavaid jooni kahes erinevas keelevariandis eesti kirjakeeles ja eesti õppijakeeles (vt Eslon, Matsak 2009).

Korpusainestiku uurimisel rakendatakse kvantitatiivset ${ }^{9}$ ja kvalitatiivset analüüsi. Nimisõnade inimene, aeg, elu ja sõna käändevormide kasutuskontekstid eraldatakse muust tekstist programmi WordSmith Tools 5.0 abil, mis reastab valimis sisalduvad sõnavormid sageduse järgi ja leiab iga sõnavormi konkordantsid ehk kasutuskontekstid. Kui sisestada korpusaines eesti keele süntaksianalüsaatorisse ja töödelda väljundit spetsiaalselt programmeeritud makrode abil, mille on välja töötanud Erika Matsak, siis tulevad esile leksikaalgrammatilised konstruktsioonid ehk vähemalt kolmest sõnavormist koosnevad keeleüksused, milles analüüsitavate nimisõnade erinevaid käändevorme on kasutatud samalaadses konstruktsioonis vähemalt kahel korral (vt Eslon, Matsak 2009: 87). Artiklis on vaadeldud neid konstruktsioone, milles nimisõnade inimene, aeg, elu ja sõna mingit kindlat käändevormi on esinenud viis ja enam korda. Nii on võimalik omavahel siduda käändevormid ja kindlat liiki leksikaalgrammatilised konstruktsioonid, milles käändevorme on kasutatud, ning sel moel välja tuua erinevate keelekasutajate eelistused käändevormide valikul (lähemalt konstruktsioonitüüpidest, nende leksikaalgrammatilistest variantidest ning tendentsidest eesti kirjakeele ja õppijakeele morfosüntaksis vt Eslon 2009).

\section{Korpusainestiku võrdleva uurimise eesmärk}

Eesmärk on välja tuua grammatiliste ehk abstraktsete käänete vormisagedus valimis ning leida, missuguseid konkreetseid käändevorme on viis ja enam korda kasutatud leksikaalgrammatilistes konstruktsioonides eelistatud. Järgnevalt saab omavahel võrrelda kirjakeele ja õppijakeele andmeid. Ilmnenud sarnasuste ja erinevuste alusel saab kindlaks

\footnotetext{
9 Analüüsi on teostanud Erika Matsak, kasutades selleks erinevaid statistilisi meetodeid (täpsemalt vt Eslon, Matsak 2009: 87-89).
} 
teha, missugused tendentsid grammatiliste käänete kasutamisel on nimetatud keelevariantidele omased. Nii peaks olema võimalik saada selgem ettekujutus muutustest eesti keele käändegrammatikas. Käesolevas artiklis piirdutakse grammatiliste käänete sageduse ja kasutuseelistuste kirjeldamisega ning nende variatiivsusega objektikäände funktsioonis.

\section{Probleemist lähemalt}

Senistes eesti kirjakeele empiirilistes uurimustes on täheldatud grammatiliste käänete hajusust ning märgitud, et objekti funktsioonis eelistatakse genitiivile enamasti partitiivi, kusjuures mõlemat käänet saab edukalt asendada nominatiiviga (Tauli 1968: 62-63; Kont 1963; Rajandi, Metslang 1979), mis tegelikult näiteks eesti-inglise kakskeelsete laste keelekasutuses (Torn 2003) ja täiskasvanute eesti õppijakeeles (Pool 2007 jt) toimibki. Valter Tauli on soovitanud keelekorraldajatel järgida elavat keelekasutust (st loomuliku morfoloogia põhimõtteid) ning kallutada grammatiliste käänete valik nominatiivi kasuks (Tauli 1968: 63). Kui tegu on nii keerulise alaga nagu objekt, mille kohta saab hea ülevaate juba Wilhelm Grünthali uurimusest (W. Grünthal 1941), siis on täiesti tavaline, et keelekasutajad püüavad keele grammatilist süsteemi enda jaoks selgemaks ja loomulikumaks muuta (Keevallik jt 2006: 610). Kõik, mis on loomulik, on keelele tüpoloogiliselt omane ning seotud sagedasemate ja markeerimata keeleüksustega.

Grammatiliste käänete vähene diferentseeritus ja üsna vaba varieeruvus objekti funktsioonis on märk keelesüsteemi arengust universaalses grammatisatsiooniprotsessis ${ }^{10}$. Grammatiliste käänete hajusus viib loomulikku rada pidi käänete funktsionaalse potentsiaali avardumise ning käändeparadigma lühenemiseni. Ajapikku kinnistub teatud käändevormide kasutus kindlate grammatiliste tähenduste väljendamisel. Näiteks Aet Lees on võrrelnud eesti ja soome keele transitiivverbide

10 Grammatisatsiooni kohta vt Ehala 1996; Heine, Kuteva 2002; Metslang 1994; 2002; 2006; Maisak 2005: 37-98; Penjam 2006; Habicht, Penjam 2006 jt. 
objekti käänet ning jõudnud järeldusele, et 17.-18. sajandil kulges grammatiliste käänete veelahe ainsuse akusatiivi ja partitiivi vahel. Akusatiivi mõistet pole Lees piiritlenud, pidades selle all silmas mittepartitiivset objektikäänet, mis mitmuses on homonüümne nominatiiviga ja ainsuses genitiiviga. Leesi järgi oli niisuguse akusatiivi kasutus soomekeelses Piibli tõlkes valdav. Võrdlemine lõuna- ja põhja-eesti murdekeelsete Piibli tõlgetega näitas, et objektikäändena oli mõlemal juhul ülekaalus partitiiv, akusatiivi esines rohkem põhja-eesti murdes. Edasisi muutusi soome ja eesti keele objektikäänetes on Lees vaadelnud Aleksis Kivi "Seitsme venna" originaali ja 1924. aastal tehtud tõlke alusel. Tulemus on enam-vähem proportsionaalne Piibli tõlke statistikaga: eesti keeles on ülekaalus partitiiv $(64,7 \%)$, samas kui soome keeles valdavad akusatiiv (50,6\%) ja partitiiv (49,4\%), vt Lees 2004. Nii eesti kui ka soome keele grammatiliste käänete vormistatistika näitab, kuidas akusatiiv on aja jooksul taandunud ning esile on kerkinud partitiiv. Ka järgnevate perioodide keelekasutus ${ }^{11}$, eriti aga viimase aja tähelepanekud, viitavad partitiivi suuremale kasutusele objekti funktsioonis (kirjakeele kohta vt Tamm 2004: 207-222 ja Habicht 2006; eesti õppijakeele osas vt Pool 2007; Metslang jt 2003: 75-79, 83-85, 126-131).

1980-ndatel aastatel tehtud soome keele objektikäänete statistikas oli 4500 käändekasutuse kohta 44\% partitiivi, 16\% genitiivi ja 17\% nominatiivi (vt Hakulinen, Karlsson 1988: 181-182). Värskematel andmetel moodustavad grammatilised käänded soome keeles $76 \%$ kõigist käändekasutustest, kusjuures sagedasemad vormid on hoopis ainsuse nominatiiv $(35,24 \%)$ ja genitiiv $(15,69 \%)$, järgnevad mitmuse nominatiiv (9,89\%), ainsuse partitiiv (7,65\%), mitmuse genitiiv (3,85\%), ainsuse illatiiv (3,79\%), mitmuse partitiiv (3,50\%) jne. Ainsuse akusatiivi (minut, sinut) esines valimis $0,04 \%$, mitmuse akusatiivi $0,01 \% .^{12}$

11 Vt V. Tauli objektnoomeni käändekasutuse statistilisi andmeid F. Tuglase, A. Mälgu ja T. Künnapase teoste esimese viiekümne lehekülje alusel: enamasti kasutatakse partitiivobjekti, totaalobjekt on erand; objektireegleid saab lihtsustada nominatiivi kasuks (Tauli 1968: 87).

12 Vt http://www.cs.tut.fi/ jkorpela/finnish-cases.html (5.11.2007). 
Värskeimad statistilised andmed eesti kirjakeele grammatiliste käänete kohta (vt tabel 1) näitavad, et EKI korpuses on valdavateks käändevormideks ainsuse partitiiv ja nominatiiv, järgnevad ainsuse genitiiv ning mitmuse nominatiiv, genitiiv ja partitiiv. Teatud määral sõltub käändevormide sagedus ka sõna tähendusest: näiteks sõna elu sagedamad käänded on ainsuse inessiiv (324 näidet) ja elatiiv (206 näidet), sõna aeg oli sage ainsuse partitiivis (1268 näidet), nominatiivis (1168 näidet) ja adessiivis (1020 näidet). Samas ei muuda see käändesageduse keskmist tulemust, mille järgi eesti kirjakeele sagedasemad käändevormid on ainsuse partitiiv ja nominatiiv. Vahe nende vormide sageduses pole kuigi oluline, ent varasemate uuringutega võrreldes (vt eespool) on nii eesti kui ka soome keeles nominatiivi kasutamine tunduvalt avardunud, eesti keeles suuresti genitiivi arvelt (vt tabel 1).

TABEL 1. Grammatiliste käändevormide sagedus EKI tekstikorpuses (nelja sagedasema nimisõna näitel)

\begin{tabular}{|l|c|c|c|c|}
\hline Käänded & inimene & sõna & elu & aeg \\
\hline SG.NOM & 960 & 397 & 184 & 1168 \\
\hline PL.NOM & 1164 & 353 & 8 & 184 \\
\hline SG.GEN & 765 & 233 & 159 & 310 \\
\hline PL.GEN & 598 & 293 & 0 & 184 \\
\hline SG.PART & 1421 & 248 & 81 & 1268 \\
\hline PL.PART & 704 & 72 & 5 & 114 \\
\hline
\end{tabular}

Eesti keeles on nominatiivi/partitiivi vastandus iseloomulik ka totaalja partsiaalobjektile, märgata võib nihkeid eesti keele nimisõna grammatiliste käänete markeerimatuses/markeerituses. Eesti keele süsteemi seisukohalt on kõige markeerimatumad käänded genitiiv ja nominatiiv ja kõige markeeritum partitiiv (vt Ehala 1997: 373 jj). See süsteemne omadus kajastub ka EKI korpuse käändevormide statistikas. Järelikult on nominatiivi markeerimatus kujunemas totaal- ja partsiaalobjekti vastandust iseloomustavaks nähtuseks. 
Tegu on teatud grammatiliste vormide järk-järgulise üldistumisega, millega on kaasnenud nende funktsionaalse potentsiaali avardumine. Seda nähtust ei saa pidada kontaktsituatsioonis tekkinud keelemuutuseks (ingl contact-induced grammaticalization), milles suunavat rolli pidanuks mängima analoogia mudelkeele grammatiliste konstruktsioonidega või mudelkeele grammatiliste kategooriate ja konkreetsete väljendusvahendite kopeerimine ${ }^{13}$. Kui eeldada, et eesti ja soome keele grammatiliste käänete analoogset arengut on mõjutanud kontaktsituatsioon vene keelega, siis oleksid nendes keeltes pidanud ajapikku ilmnema samalaadsed muutused kui karjala murdekeeleski (vt Naumova 2006: 16, 10): partitiivi on hakatud kasutama totaalobjektina juhul, kui objektnoomen tähistab elusolendit; mõned liikumisverbid hakkavad nõudma enda järel partitiivi; vene keele mõjul on toimunud nihked rektsioonimustrites, verbirektsioon on muutunud varieeruvaks jne. Sarnaseid jooni pole ei soome ega eesti keele grammatiliste käänete uurijad seni esile toonud. Järelikult võib arvata, et nominatiivistumine on eesti ja soome keele süsteemide loomuliku arengu tulemus, mis pole olnud tingitud vahetutest keelekontaktidest ja ei ole seletatav võõrmõjuna ${ }^{14}$. Seda järeldust kinnitavad samuti võrdlusandmed eesti õppijakeele käändevormide sageduse ja kasutuseelistuste kohta (vt tabel 2).

Tabelis 2 toodud andmed näitavad, et erinevates keelekasutusvariantides on eelistatud neid leksikaalgrammatilisi konstruktsioone, milles nimisõnad inimene, aeg, elu ja sõna esinevad valdavalt ainsuse ja mitmuse nominatiivis (pikemalt vt Eslon, Matsak 2009: 89, 91-92, 94, 96-97).

\footnotetext{
13 Nende protsesside kohta vt Heine, Kuteva 2003, 2008; Aikhenvald 2007: 1-66.

14 Probleemist vt Hopper, Traugott 1993; Harris, Campbell 1995; Diewald 1997; Pajunen 1998; R. Grünthal 2003; Penjam 2006; Itkonen 2005; Metslang 2006, 2002, 1994; Ehala 1996 jt.
} 
TABEL 2. Käändevormide sagedus ja kasutuseelistused EKI korpuses ja $E V K K-s$

\begin{tabular}{|c|c|c|c|c|}
\hline & $\begin{array}{l}\text { Sagedus } \\
\text { EKI } \\
\text { korpuses }\end{array}$ & $\begin{array}{l}\text { EKI korpuses sage- } \\
\text { dastes konstrukt- } \\
\text { sioonides eelistatud } \\
\text { käändevormid }\end{array}$ & $\begin{array}{l}\text { Sagedus } \\
\text { EVKK-s }\end{array}$ & $\begin{array}{l}\text { EVKK-s sagedas- } \\
\text { tes konstruktsioo- } \\
\text { nides eelistatud } \\
\text { käändevormid }\end{array}$ \\
\hline inimene & $\begin{array}{l}\text { SG.PART } \\
\text { PL.NOM } \\
\text { SG.NOM } \\
\text { SG.GEN } \\
\text { PL.GEN }\end{array}$ & $\begin{array}{l}\text { SG.NOM } \\
\text { PL.NOM } \\
\text { SG.GEN } \\
\text { SG.PART } \\
\text { PL.PART }\end{array}$ & $\begin{array}{l}\text { SG.NOM } \\
\text { PL.NOM } \\
\text { PL.GEN } \\
\text { SG.PART } \\
\text { PL.PART } \\
\text { SG.GEN } \\
\end{array}$ & $\begin{array}{l}\text { SG.NOM } \\
\text { PL.NOM } \\
\text { SG.GEN } \\
\text { SG.PART } \\
\text { PL.GEN } \\
\text { PL.PART } \\
\end{array}$ \\
\hline sõna & $\begin{array}{l}\text { SG.NOM } \\
\text { PL.NOM } \\
\text { PL.GEN } \\
\text { SG.PART } \\
\text { SG.GEN }\end{array}$ & $\begin{array}{l}\text { SG.NOM } \\
\text { SG.GEN } \\
\text { PL.GEN }\end{array}$ & $\begin{array}{l}\text { PL.NOM } \\
\text { PL.KOM } \\
\text { SG.NOM } \\
\text { PL.GEN } \\
\text { SG.KOM } \\
\end{array}$ & $\begin{array}{l}\text { SG.NOM } \\
\text { PL.GEN } \\
\text { SG.PART }\end{array}$ \\
\hline elu & $\begin{array}{l}\text { SG.INES } \\
\text { SG.ELAT } \\
\text { SG.NOM } \\
\text { SG.GEN } \\
\text { SG.PART }\end{array}$ & SG.NOM & $\begin{array}{l}\text { SG.INES } \\
\text { SG.NOM } \\
\text { SG.GEN } \\
\text { SG.PART } \\
\text { SG.ELAT } \\
\end{array}$ & $\begin{array}{l}\text { SG.NOM } \\
\text { SG.GEN } \\
\text { SG.PART }\end{array}$ \\
\hline aeg & $\begin{array}{l}\text { SG.PART } \\
\text { SG.NOM } \\
\text { SG.ADS } \\
\text { SG.GEN } \\
\text { PL.NOM } \\
\text { PL.GEN }\end{array}$ & $\begin{array}{l}\text { SG.NOM } \\
\text { SG.PART }\end{array}$ & $\begin{array}{l}\text { SG.ADS } \\
\text { SG.PART } \\
\text { SG.NOM } \\
\text { SG.GEN }\end{array}$ & $\begin{array}{l}\text { SG.ADS } \\
\text { PL.GEN } \\
\text { SG.PART } \\
\text { SG.NOM } \\
\text { SG.GEN }\end{array}$ \\
\hline
\end{tabular}




\section{Käändegrammatikas ilmnenud muutuste põhjusi}

Grammatiliste käänete vormivariatiivsus objekti funktsioonis sõltub ühelt poolt verbist ja teisalt noomeni käändegrammatikast. Kui on näha muutusi käändevormide sageduses ja kasutuseelistustes, siis on järelikult muutunud ka kehtinud tasakaal noomeni- ja verbigrammatika vahel. Küsimus on seotud aspektitähenduste edastamisega objektnoomeni käände abil, kui nominatiivne-genitiivne objekt tähistab tegevuse piiritletust (teelisust) ning partitiiv tegevuse piiritlematust (ateelisust).

Seoses aspektitähenduste väljendamisega on viimasel ajal eesti keele verbigrammatikas, derivatsioonis ja semantikas märgata erinevaid arenguid, nt on tekkimas lihtverbi ja analüütilise verbi aspektitähenduslik vastandus nagu tülitsema/tülli minema, nõustuma/nõus olema, tervenema/ terveks saama, soojendama/soojaks tegema jt, milles lihtverb kirjeldab piiritlemata ja analüütiline piiritletud tegevust (vt Eslon 2004: 101-104). Huvipakkuvaid tähelepanekuid eesti keele transitiivverbide kohta võib leida Natalia Vaissilt (2004). Jaganud transitiivverbid objektikäände valiku ja tegevuse aspektuaalse semantika alusel partitiivseteks (lihtverbe $46,2 \%$ / ühendverbe 7,1\% kõikidest analüüsitud verbidest), perfektiivseteks (vastavalt 9,4\% / 78,4\%) ning aspektilisteks (15,9\% / 7,8\%), on Vaiss eraldi välja toonud mitme aspektuaalse tähendusega verbid, millest 28,5\% moodustavad lihtverbid ja 6,7\% ühendverbid. Nende puhul võib isegi väike tähendusnüansi nihe muuta verbi rektsioonistruktuuri ja seega objektkäände valikut (Vaiss 2004: 65). Näiteks: Eestlased röövisid Soomes jälle ühte kullaäri (mida? ainsuse partitiiv) - kirjeldatakse järjekordset juhtumit teiste samalaadsete reas; neid juhtumeid on olnud, oli äsja ja saab ka tulevikus olema. Verbi röövima on siin kasutatud tähenduses 'paljaks, tühjaks tegema'. Kui aga objektiks on inimene nagu lauses Eestlased röövisid Soomes jälle ühe immigrandi (kelle? ainsuse genitiiv), siis on verbi kasutatud tähenduses 'endaga kaasa viima, ära röövima' kirjeldatud tegevus on finaalne, immigrant on röövitud. Kui aga rööviti üht immigranti (keda? ainsuse partitiiv), siis on verbi röövima kasutatud jälle tähenduses 'paljaks, tühjaks tegema'. Vaissi uurimuse järgi on sar- 
naste verbide hulk eesti keeles oodatust suurem. Peale selle on ligi $26 \%$ kõikidest Vaissi sõnastikus sisalduvatest partitiivverbidest potentsiaalselt aspektilised, st võivad olla kasutatud ka perfektiivsetena, ning 62,5\% perfektiivsetest lihtverbidest ja 24,8\% perfektiivsetest ühendverbidest on kasutatavad imperfektiivsetena ja niisiis koos partitiivse objektiga. Seega kasvatavad potentsiaalselt aspektilised partitiiv- ja perfektiivverbid jõudsasti aspektverbide klassi, samas kui osade aspektverbide semantika tuhmub sedavõrd, et neid saab võrdväärselt kasutada nii partitiiv-, potentsiaalselt partitiiv- kui ka perfektiiv- ja potentsiaalselt perfektiivverbidena, soosides sel viisil objektikäänete variatiivsuse suurenemist.

Sisutühjade aspektverbide, potentsiaalselt aspektiliste partitiiv- ja perfektiivverbide hulk on eesti keeles suurenemas (andma, avaldama, hoidma, jätma, laskma, kirjutama, lööma, kandma, lugema, mõõtma, murdma, heitma, hindama, jagama, kaotama, kasvatama, keerama, kiskuma, kutsuma, kuulama, kuulutama, leidma, lahutama, köitma, looma, lõikama, lükkama, lülitama, maksma, matma, mõtlema, mängima, märkima, määrama, määrima, neelama, nimetama, nõudma, omama jt). Tegu on leksika ja süntaksi piirimail oleva nähtusega, mille kirjeldamisraskusi on eesti keele verbide klassifitseerimisel ka varemalt kogetud ${ }^{15}$. Enamus neist lihtverbidest kuulub keelesüsteemi tuumelementide hulka (vt Erelt 2001; Pajusalu jt 2004), mille puhul semantiline hajusus on korrelatsioonis nende polüfunktsionaalsuse ja järk-järgulise grammatiseerumisega. Seetõttu on loogiline, et ka lihtverbide leksikaalselt väljendatud aspektilisus tuhmub, muutub mitmeti interpreteeritavaks, mille tulemusel aspektitähenduse konkretiseerimine nihkub verbilt noomenile. Tegelikult on eesti keele objektikäänete variatiivsus ja võimalus valida erinevate käänete vahel samasugune aspektitähenduste diferentseerimise vahend nagu vene verbi imperfektiivse ja perfektiivse aspekti grammatilised vormid. Tegu on keeltevahelise analoogiaga, milles oma osa kuulub nii verbi semantikale kui grammatilistele ajavormidele. Selles mõttes on mõlema keele noomeni- ja verbivormide funktsionaalne potentsiaal sarnane. Henno Rajandi ja Helle Metslang on märkinud, et

15 Eesti keele verbide klassifitseerimise kitsaskohtadest vt Tamm 2003: 639-653. 
kui noomeni klassi kuuluvad sõnad jaotuvad referentsiaalselt asjadeks ja aineteks ning kujutavad endast ruumiliselt terviklikku substantsi või selle puudumist, siis verbi jaoks on samad seosed väljendatud tegevuse ajalise kindlapiirilisuse või selle puudumisega (Rajandi, Metslang 1979: 10). See nähtus ei piirdu ühe keele süsteemi sisemise või tüpoloogiliselt sarnaste keelte vahelise analoogiaga, vaid on universaalne seaduspära. Ka varematel aegadel on muutused verbisüsteemis esile kutsunud noomeni funktsioonide ümbermõtestamist. Näiteks vene keele ajavormide paradigma lihtsustumine tingis verbi finiitvormile järgnenud sihitiskäändelise vormi funktsionaalse potentsiaali avardumise: säilitades noomenile omased tunnused, võttis noomenivorm üle ka verbile omased funktsioonid. Jutt on vene keele infinitiivist ja spetsiifilistest infinitiivlausetest. Niisugustes protsessides tuleb ilmsiks keelesüsteemi sisemise kompensatoorsuse mehhanism. Tegu on analoogiale tuginevate keelesiseste ja keeltevaheliste iseseisvate arengutega universaalses grammatisatsiooniprotsessis.

Samast seisukohast tuleks lähtuda ka objektnoomeni käändegrammatikas kulgevate protsesside interpreteerimisel. Grammatiliste käänete variatiivsuse põhjusi võib olla mitmeid: arengud eesti keele muutemorfoloogias (vt Ehala 1997), grammatiline homonüümia, käändeparadigma lühenemine, keele loomulik lihtsustumine jm. Olulist tähendust objekti käändevariatiivsuse avardumisel omab ilmselt kõneakti pragmaatika ja lause infostruktuur. On piisavalt tekstinäiteid, mille alusel saab teha üldise järelduse, et kõneleja jaoks pole oluline ei reema positsioonis oleva objekti totaalsus/partsiaalsus ega tegevuse aspektilise tähenduse piiritlemine. Oluline on objektiga edastatava uue informatsiooni sisu: On palju lõike, mida peab tegema Riigikogu ja valitsus ning kui midagi sel-

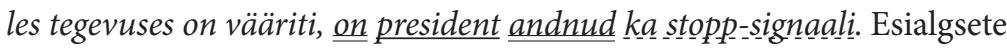
tähelepanekute alusel võib öelda, et sedalaadi nähtus pole vaid prosoodiaga seotud või mõistetav vormihomonüümiast lähtudes. Üsna sageli tuleb ette näiteid, kus vormi poolest selgelt eristuvad kolm grammatilist käänet on objekti funktsioonis kasutatuna kas osaliselt või täielikult

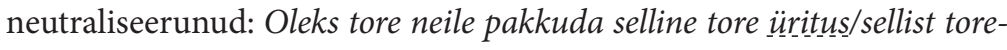


dat üritust (nominatiivi/partitiivi vastanduse kadu); Temast võib saada inimene/innimese/inimest_ (nominativi/genitiivi/partitiivi eristamine ei ole obligatoorne) jne. Kõneakti pragmaatikast tulenevalt on oluline esile tuua uue informatsiooni sisu, mis võtab ära vajaduse markeerida käändega nii tegevuse aspektilisust kui ka objekti totaalsust/partsiaalsust. Seetõttu valib keelekasutaja eesti keelele tüpoloogiliselt omase loomuliku lihtsustamise tee ja langetab oma valiku nominatiivi kasuks (vt eespool tabel 2, samuti W. Grünthali, V. Tauli jt tähelepanekud). Kui eesti keele käändemorfoogias puuduksid sisemised eeldused grammatiliste käänete neutraliseerumiseks reema (objekti) positsioonis, siis oleksid sedalaadi arengud olemata või ilmneksid keelekontaktist põhjustatud võõrmõjulise muutusena, millest eespool oli juttu seoses karjala murdekeele akusatiivistumise ja nihetega verbirektsioonis.

\section{Lõpetuseks}

Eesti keele grammatiliste käänete variatiivsus, nominatiivi markeerimatus ja üldistumine elavas keelekasutuses, mis on jälgitav nii eesti kirjakeele kui ka õppijakeele vormisageduses ja käändevormide kasutuseelistustes, viitavad sellele, et eesti keele grammatiliste käänete funktsioonid on avardunud, samas kui vorme nende funktsioonide väljendamiseks jääb vähemaks. Selle tulemusel lähevad grammatiliste käänete senised kasutusreeglid vastuollu tegeliku keelekasutusega ning õpetajatel, toimetajatel ja keelekorraldajatel puudub kindel alus, millele oma töös tugineda: vanad reeglid justkui ei sobi, kuid uued pole veel päriselt välja kujunenud. Keelekasutajad lähevad intuitiivselt ja oma keeletajule tuginedes reeglistiku lihtsustamise ning loomulikumaks muutmise teed. 


\section{Tänusõnad}

Tööd on toetanud riikliku programmi "Eesti keele keeletehnoloogiline tugi (2006-2010)" projekt "VAKO: Eesti vahekeele korpuse keeletarkvara ja keeletehnoloogilise ressursi arendamine".

\section{Lühendid}

$\begin{array}{ll}\text { GEN } & \text { genitiiv } \\ \text { NOM } & \text { nominatiiv } \\ \text { PART } & \text { partitiiv } \\ \text { PL } & \text { mitmus } \\ \text { SG } & \text { ainsus }\end{array}$

\section{Kirjandus}

Aikhenvald, Alexandra Y. 2007. Grammars in contact: A cross-linguistic perspective. - Alexandra Y. Aikhenvald, R. M. W. Dixon (Eds.). Grammars in Contact: A Cross-Linguistic Typology. Explorations in Linguistic Typology Series 4. Oxford: Oxford University Press, 1-66.

Aikhenvald, Alexandra Y. 2002. Language Contact in Amazonia. Oxford: Oxford University Press.

Argus, Reili 2008. Eesti lastekeelekorpuse morfoloogiliste vigade märgendamisest ja liigitamisest. - Pille Eslon (Toim.). Õppijakeele analüüs: võimalused, probleemid, vajadused. Tallinn Ülikooli eesti filoloogia osakonna toimetised 10. Tallinn: Tallinna Ülikooli Kirjastus, 11-30.

Behrens, Heike (Ed.) 2008. Corpora in Language Acquisition Research: History, Methods, Perspectives. Trends in Language Acquisition Research 6. Amsterdam, Philadelphia: Benjamins.

Cobb, Tom 2003. Analyzing late interlanguage with learner corpora: Québec replications of the three European studies. - The Canadian Modern Language Review 59, 3, 393-423.

Diewald, Gabriele 1997. Grammatikalisierung. Eine Einführung in Sein und Werden grammatischen Formen. Germanistische Arbeitsberichten 36. Tübingen: Verlag Max Niemeyer.

Ehala, Martin 1996. Integreeritud keeleteaduse võimalikkusest tänapäeva keeleteaduses (II). - Keel ja Kirjandus 6, 375-384; 7, 447-460. 
Ehala, Martin 1997. Eesti morfoloogia olemus. - Keel ja Kirjandus 6, 370-383.

Ehala, Martin 2009. Keelekontaktide mõju eesti sihitiskäänete kasutamisele. - Keel ja Kirjandus 3, 182-204.

Erelt, Mati 2001. Some notes on the grammaticalization of the verb pidama in Estonian. - Mati Erelt (Ed.). Estonian: Typological Studies V. Publications of the Department of Estonian of the University of Tartu 18. Tartu: Tartu Ülikool, 7-25.

Eslon, Pille 2004. O grammatikalizatsii analiticheskikh glagolov estonskogo iazyka. - Linguistica Uralica XL, 2, 95-108.

Eslon, Pille 2008. Käändevormide kasutussageduse võrdlus eesti õppijakeeles ja kirjakeeles. - Pille Eslon (Toim.). Õppijakeele analüüs: võimalused, probleemid, vajadused. Tallinn Ülikooli eesti filoloogia osakonna toimetised 10. Tallinn: Tallinna Ülikooli Kirjastus, 31-66.

Eslon, Pille 2009. Eestikeelses tekstiloomes eelistatud konstruktsioonid ja käändevormid. - Pille Eslon, Katre Õim (Toim.). Korpusuuringute metodoloogia ja märgendamise probleemid. Tallinna Ülikooli eesti filoloogia osakonna toimetised 11. Tallinn: Tallinna Ülikooli Kirjastus, 30-53.

Eslon, Pille, Erika Matsak 2009. Eesti keele kasutusvariandid: korpusest tulenev ja korpuspõhine võrdlev analüüs. - Eesti Rakenduslingvistika Ühingu aastaraamat $5,79-110$.

Gabrielatos, Costas 2007. If-conditionals as modal colligations: A corpus-based investigation. - Matthew Davies, Paul Rayson, Susan Hunston, Pernilla Danielsson (Eds.). Proceedings of the Corpus Linguistics Conference: Corpus Linguistics 2007. Birmingham. http://www.corpus.bham.ac.uk/ corplingproceedings07/paper/256 Paper.pdf (24.03.2009).

Granger, Sylviane (Ed.) 1998. Learner English on Computer. London: Longman.

Grünthal, Riho 2003. Finnic Adpositions and Cases in Change. Suomalais-Ugrilaisen Seuran toimituksia 244. Helsinki: Finno-Ugrian Society.

Grünthal, Wilhelm 1941. Itämerensuomalaisten kielten yksikön nominatiivi objektin edustajana aktiivin yhteydessä. Lauseopillinen tutkimuskoe. Suomalaisen Kirjallisuuden Seuran toimituksia 218. Helsinki: Suomalaisen Kirjallisuuden Seura.

Habicht, Külli 2006. Meie muutuv keel. - Oma Keel 1, 12-19.

Habicht, Külli, Pille Penjam 2006. Kaassõna keeleuurija ja -kasutaja käsitluses. Emakeele Seltsi aastaraamat 52 (2005), 51-68.

Hakulinen, Auli, Fred Karlsson 1988. Nykysuomen lauseoppia. Suomalaisen Kirjallisuuden Seuran toimituksia 350. Helsinki: Suomalaisen Kirjallisuuden Seura. 
Harris, Alice C., Lyle Campbell 1995. Historical Syntax in Cross-Linguistic Perspective. Cambridge Studies in Linguistics 74. Cambridge: Cambridge University Press.

Haspelmath, Martin, Thomas Müller-Bardey 2001. Valence change. http://email. eva.mpg.de/ haspelmt/2005val.pdf (12.08.2008).

Heine, Bernd, Tania Kuteva 2002. On the role of context in grammaticalization. - Ilse Wischer, Gabriele Diewald (Eds.). New Reflections on Grammaticalization. Typological Studies in Language Series 49. Amsterdam, Philadelphia: Benjamins, 83-101.

Heine, Bernd, Tania Kuteva 2008. Constraints on contact-induced linguistic change. - Journal of language contact - THEMA 2. Language Contact and the Dynamics of Language: Theory and Implications, 57-89. http://www. jlc-journal.org (8.07.2008).

Hoey, Michael, Michaela Mahlberg, Michael Stubbs, Wolfgang Teubert (Eds.) 2007. Text, Discourse, and Corpora: Theory and analysis. With an introduction by John Sinclair. Corpus and Discourse Series. London, New York: Continuum International.

Holroyd, Clay B., Michael G. H. Coles 2002. The neural basis of human error processing: Reinforcement learning, dopamine, and the error-related negativity. - Psychological Review 109, 4, 679-709. doi:10.1037/0033-295X.109.4.679

Hopper, Paul, Elizabeth Traugott 1993. Grammaticalization. Cambridge: Cambridge University Press.

Itkonen, Esa 2005. Analogy as Structure and Process. Approaches in Linguistics, Cognitive Psychology and Philosophy of Science. Human Cognitive Processing 14. Amsterdam, Philadelphia: Benjamins.

Jantunen, Jarmo 2007. Oppijansuomen piirteitä korpusvetoisesti. - Pirkko Muikku-Werner, Ossi Kokko, Hannu Remes (Toim.). Virsu III: Suomalais-ugrilaisia kohdekieliä ja kontakteja. Studies in Language 42. Joensuu: Joensuun yliopisto, 69-84.

Jantunen, Jarmo 2008. Haasteita oppijankielen korpusanalyysille: oppijankielen universaalit. - Pille Eslon (Toim.). Õppijakeele analüüs: võimalused, probleemid, vajadused. Tallinn Ülikooli eesti filoloogia osakonna toimetised 10. Tallinn: Tallinna Ülikooli Kirjastus, 67-92.

Kaivapalu, Annekatrin 2008. Lähtekeele mõju korpuspõhine uurimine. - Pille Eslon (Toim.). Õppijakeele analüüs: võimalused, probleemid, vajadused. Tallinn Ülikooli eesti filoloogia osakonna toimetised 10. Tallinn: Tallinna Ülikooli Kirjastus, 93-119. 
Keevallik, Leelo, Külli Habicht, Ilona Tragel 2006. Keele muutumine kasutuskontekstis. - Keel ja Kirjandus 8, 609-625.

Kennedy, Graeme 2002. Variation in the distribution of modal verbs in the British National Corpus. - Randi Reppen, Susan M. Fitzmaurice, Douglas Biber (Eds.). Using Corpora to Explore Linguistic Variation. Studies in Corpus Linguistics 9. Amsterdam: Benjamins, 73-90.

Kont, Karl 1963. Käändsõnaline objekt läänemeresoome keeltes. Tallinn: Eesti Riiklik Kirjastus.

Langacker, Ronald W. 1999. Grammar and Conceptualization. Berlin, New York: Mouton de Gruyter.

Lees, Aet 2004. The case of the object in Early Estonian and Finnish Texts. Proceedings of the 2004 Conference of the Australian Linguistics Society. http://ses.library.usyd.edu.au/bitstream/2123/113/1/ALS-20050630-AL. pdf (6.11.2008).

Maisak, Timur A. 2005. Tipologiia grammatikalizatsii konstruktsij s glagolami dvizheniia i glagolami pozitsii. [Grammaticalization paths of motion and posture verbs: a typology.] Moscow: Iazyki Slavianskikh Kultur.

Metslang, Helle 1994. Grammatikaliseerumisest eesti ja soome keeles. - Karl Pajusalu, Valma Yli-Vakkuri (Toim.). Lähivertailuja 7. Publications of the Department of Finnish and general linguistics of the University of Turku 44. Turku, 9-32.

Metslang, Helle 2002. Grammatikalisatsiooniteooriast eesti keele taustal. - Renate Pajusalu, Ilona Tragel, Tiit Hennoste, Haldur Õim (Toim.). Teoreetiline keeleteadus Eestis. Tartu Ülikooli üldkeeleteaduse õppetooli toimetised 4. Tartu: Tartu Ülikool, 175-178.

Metslang, Helle 2006. Grammatisatsiooniteooriast tänase pilguga. - Ilona Tragel, Haldur Õim (Toim.). Teoreetiline keeleteadus Eestis II. Tartu Ülikooli üldkeeleteaduse õppetooli toimetised 7. Tartu: Tartu Ülikooli Kirjastus, $176-195$.

Metslang, Helle, Ingrid Krall, Renate Pajusalu, Kristi Saarso, Elle Sõrmus, Silvi Vare 2003. Keelehärm. Tallinn: Tallinna Ülikooli Kirjastus.

Muischnek, Kadri 2006. Verbi ja noomeni püsiühendid eesti keeles. Dissertationes philologiae Estonicae Universitatis Tartuensis 17. Tartu: Tartu Ülikooli Kirjastus. http://www.utlib.ee/ekollekt/diss/dok/2006/b1833409x/muischnek.pdf (11.11.2008).

Naumova, Marina 2006. Glagolnoie upravlenie v livvikovskom narechii karelskogo iazyka. Avtoref. dis. kand. filol. nauk. Petrozavodsk. 
Nesselhauf, Nadia 2005. Collocations in a Learner Corpus. Studies in Corpus Linguistics 14. Amsterdam, Philadelphia: Benjamins.

Orpin, Debbie 2005. Corpus linguistics and critical discourse analysis: Examining the ideology of sleaze. - International Journal of Corpus Linguistics 10, 1, 37-61. doi:10.1075/ijcl.10.1.03orp

Pajunen, Anneli (Toim.) 1998. Kieliopillistumisesta, analogiasta ja typologiasta. Suomi 185. Helsinki: Suomalaisen Kirjallisuuden Seura.

Pajusalu, Renate, Ilona Tragel, Ann Veismann, Maigi Vija 2004. Tuumsõnade semantikat ja pragmaatikat. Tartu Ülikooli üldkeeleteaduse õppetooli toimetised 5. Tartu: Tartu Ülikooli Kirjastus.

Penjam, Pille 2006. Development of the modal function of the verb tulema 'come' in written Estonian. - Linguictica Uralica XLII, 3, 167-191.

Petch-Tyson, Stephanie 1998. Writer / reader visibility in EFL written discourse. Sylviane Granger (Ed.). Learner English on Computer. London: Longman, 107-118.

Pool, Raili 2007. Eesti keele teise keelena omandamise seaduspärasusi täis- ja osasihitise näitel. Dissertationes philologiae Estonicae Universitatis Tartuensis 19. Tartu: Tartu Ülikooli Kirjastus.

Rajandi, Henno, Helle Metslang 1979. Määramata ja määratud objekt. Tallinn: Valgus.

Remchukova, Elena 2005. Kreativnyj potencial russkoj grammatiki: Morfologicheskiie resursy iazyka. [Creative potential of Russian grammar: Morphological resources of language.] Moscow.

Ringbom, Håkan 1998. Vocabulary frequencies in advanced learner English: a cross-linguistic approach. - Sylviane Granger (Ed.). Learner English on Computer. London: Longman, 41-52.

Sinclair, John 1991. Corpus, Concordance, Collocation. Oxford: Oxford University Press.

Sinclair, John 2004. Trust the Text: Language, Corpus and Discourse. London: Taylor \& Francis.

Stubbs, Michael 1996. Text and Corpus Analyzis: Computer Assisted Studies of Language and Culture. Language in Society 23. Oxford: Blackwell.

Sõrmus, Kadri 2008. Emakeeleõppija korpus. Statistiline analüüs ja veamärgendussüsteem. Magistritöö. Tartu Ülikool.

Tamm, Anne 2003. Estonian transitive verb classes, object case, and progressive. Anne Dahl, Peter Svenonius (Eds.). Proceedings of the 19th Scandinavian conference of linguistics, vol. 31.4: Finnic. Tromsø, 639-653. 
Tamm, Anne 2004. Relations between Estonian Verbs, Aspect, and Case. Doktoral dissertation. Budapest.

Tauli, Valter 1968. Keelekorralduse alused. Stockholm: Eesti Raamat.

Thomason, Sara G. 2008. Social and linguistic factors of contact-induced change. Journal of language contact - THEMA 2. Language Contact and the Dynamics of Language: Theory and Implications, 42-56. http://www.jlc-journal. org (8.07.2008).

Thomason, Sara G., Terrence Kaufman 1988. Language Contact, Creolization, and Genetic Linguistics. Berkeley, Los Angeles: University of California Press.

Tognini Bonelli, Elena 2002. Functionally complete units of meaning across English and Italian: Towards a corpus-driven approach. - Bengt Altenberg, Sylviane Granger (Eds.). Lexis in Contrast. Corpus-based approaches. Studies in Corpus Linguistics 7. Philadelphia: John Benjamins, 73-95.

Tono, Yukio, Megumi Aoki 1998. Developing the optimal learning list of irregular verbs based on the native and learner corpora. - International symposium on computer learner corpora, Second language aquisition and foreign language teaching. The Chinese University of Hong Kong, 14-16 december 1988. http://leo.meikai.ac.jp/ tono/paper/handout.pdf (5.07.2008).

Torn, Reeli 2003. Object case marking: English influence on the use of Estonian by three Estonian-English bilingual children. - Kalbotyra/Linguistics 53 (3), 126-134.

Vaiss, Natalia 2004. Eesti keele aspekti väljendusvõimalusi vene keele taustal. Magistritöö. Tallinna Ülikool.

Wurzel, Wolfgang 1984. Flexionsmorphologie und Natürlichkeit. Ein Beitrag zur morphologischen Theoriebildung. Berlin: Akademie Verlag Berlin.

\section{Pille Eslon}

Tallinna Ülikool, eesti keele ja kultuuri instituut

Narva mnt 29

10120 Tallinn, Estonia

pille.eslon@tlu.ee 


\title{
Changes in the use of Estonian grammatical cases
}

\author{
PILLE ESLON \\ Tallinn University
}

The paper compares the frequency of some Estonian grammatical cases (nominative-genitive-partitive), as well as morphological preferences, in standard Estonian and in Estonian learner language. The aim is to report on certain typological changes in Estonian, which may have been triggered by various factors (e.g. verbs losing their aspectual characteristics, aspect marked by object case alternation, certain grammatical cases expressing no significant meaning distinctions from the perspective of pragmatics) but are nevertheless formed by analogy in the general process of grammaticalization. In Estonian, these changes, especially the observation that certain alternating grammatical cases are losing their (semantic) contrasts either partially or totally, and that the preferred form of the nominal in the position of the direct object (or rhema) is the nominative case, cannot be explained by language contact unlike, for example, in Karelian dialects in which one grammatical case, i.e. the accusative, is taking over the functions of other cases.

Keywords: grammatical cases in Estonian; analogy-based language change; grammaticalization 